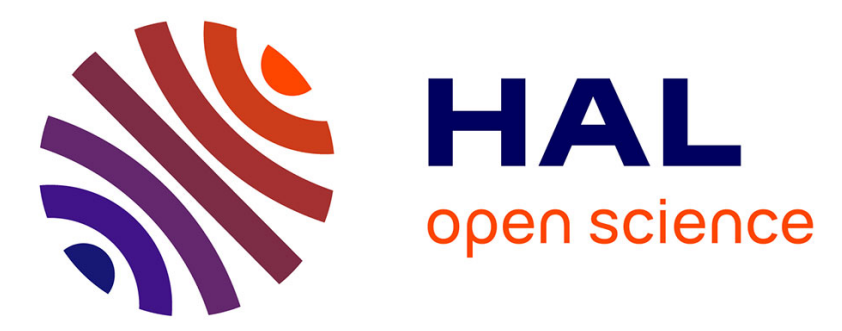

\title{
Assessing temporal variation of primary and ecosystem production in two Mediterranean forests using a modified 3-PG model
}

Angelo Nolè, Alessio Collalti, Federico Magnani, Pierpaolo Duce, Agostino

Ferrara, Giuseppe Mancino, Serena Marras, Costantino Sirca, Donatella

Spano, Marco Borghetti

\section{To cite this version:}

Angelo Nolè, Alessio Collalti, Federico Magnani, Pierpaolo Duce, Agostino Ferrara, et al.. Assessing temporal variation of primary and ecosystem production in two Mediterranean forests using a modified 3-PG model. Annals of Forest Science, 2013, 70 (7), pp.729-741. 10.1007/s13595-013-0315-7 . hal01201517

\section{HAL Id: hal-01201517 \\ https://hal.science/hal-01201517}

Submitted on 17 Sep 2015

HAL is a multi-disciplinary open access archive for the deposit and dissemination of scientific research documents, whether they are published or not. The documents may come from teaching and research institutions in France or abroad, or from public or private research centers.
L'archive ouverte pluridisciplinaire HAL, est destinée au dépôt et à la diffusion de documents scientifiques de niveau recherche, publiés ou non, émanant des établissements d'enseignement et de recherche français ou étrangers, des laboratoires publics ou privés. 


\title{
Assessing temporal variation of primary and ecosystem production in two Mediterranean forests using a modified 3-PG model
}

\author{
Angelo Nolè • Alessio Collalti • Federico Magnani • Pierpaolo Duce • \\ Agostino Ferrara • Giuseppe Mancino - Serena Marras • Costantino Sirca • \\ Donatella Spano • Marco Borghetti
}

Received: 11 January 2013 / Accepted: 12 July 2013 /Published online: 28 August 2013

(C) INRA and Springer-Verlag France 2013

\begin{abstract}
- Context Forest ecosystem carbon uptake is heavily affected by increasing drought in the Mediterranean region.

- Aims The objectives of this study were to assess the capacity of a modified 3-PG model to capture temporal variation in gross primary productivity (GPP), and ecosystem net carbon uptake (NEE) in two Mediterranean forest types.
\end{abstract}

\section{Handling Editor: Barry Alan Gardiner}

Contribution of the co-authors A. Nolè: designing, assembling and running the model, coordinating the experimental work, writing the paper; A. Collalti: providing eddy flux data, contributing to data analysis; F. Magnani: contributing to model structure; A. Ferrara: contributing to data analysis; G. Mancino: contributing to data analysis; P. Duce, S. Marras, C. Sirca, D. Spano, providing eddy flux data; M. Borghetti, coordinating the research project, contributing to model structure, writing the paper.

A. Nolè $\cdot$ A. Ferrara $\cdot$ G. Mancino $\cdot$ M. Borghetti $(\bowtie)$

Scuola di Scienze Agrarie, Forestali, Alimentari e Ambientali,

Università della Basilicata, viale dell'Ateneo Lucano 10,

85100 Potenza, Italy

e-mail: marco.borghetti@unibas.it

\section{A. Collalti}

Divisione Impatti su Agricoltura, Foreste ed Ecosistemi Naturali (IAFENT), Centro euroMediterraneo sui Cambiamenti Climatici (CMCC), via Pacinotti 5, 00100 Viterbo, Italy

\section{F. Magnani}

Dipartimento di Colture Arboree, Università di Bologna,

via Fanin 46, 40127 Bologna, Italy

\section{P. Duce}

IBIMET-CNR, Traversa la Crucca 3, Regione Baldinca, I-07100 Li Punti, Sassari, Italy

S. Marras $\cdot$ C. Sirca $\cdot$ D. Spano

Dipartimento di Scienza della Natura e del Territorio,

Università di Sassari, via E. De Nicola 9, 07100 Sassari, Italy
- Methods The model was upgraded from a monthly (3-PG) to a daily time step ( $\left.3-\mathrm{PG}_{\mathrm{day}}\right)$, and a soil water balance routine was included to better represent soil water availability. The model was evaluated against seasonal GPP and NEE dynamics from eddy covariance measurements.

- Results Simulated and measured soil water content values were congruent throughout the study period for both forest types. 3-PG $\mathrm{PG}_{\text {day }}$ effectively described the following: GPP and NEE seasonal patterns; the transition of forest ecosystems from carbon sink to carbon source; however, the model overestimated diurnal ecosystem respiration values and failed to predict ecosystem respiration peaks.

- Conclusions The model served as a rather effective tool to represent seasonal variation in gross primary productivity, and ecosystem net carbon uptake under Mediterranean droughtprone conditions. However, its semi-empirical nature and the simplicity inherent in the original model formulation are obstacles preventing the model working well for short-term daily predictions.

Keywords Carbon balance $\cdot$ Forest $\cdot$ Ecosystem . Mediterranean $\cdot$ Drought $\cdot$ Model

\section{Introduction}

Climatic projections predict significant increases in temperature and decreases in precipitation, in the Mediterranean basin, making it a highly vulnerable area (IPCC 2007). In particular, Mediterranean forest vegetation is forecast to undergo continual change as a result of the interacting effects of climatic and land use changes, with likely effects on hydrological balance at the watershed and regional scale, and the supply of ecosystem services (Giorgi 2006; Vitale et al. 2012). Recent reviews and experimental evidence highlighted the potential of water stress to 
cause extensive forest dieback (Anderegg et al. 2012) and the vulnerability of Mediterranean forest trees to severe summer droughts (Nardini et al. 2013).

Transition from positive to negative carbon balance in Mediterranean forest ecosystems, as a consequence of increasing environmental constraints, is a crucial process which might have profound consequences on forest persistence and forest vegetation dynamics. For this reason, carbon uptake as a functional response to climatic variables is pivotal information to forecast the effects of climate change, evaluate the potential of forest vegetation in drought-prone environments, and design conservation strategies from an adaptive management perspective (Lindner et al. 2010).

Process-based models are the most feasible way to assess functional responses to climatic variables over large spatial and temporal scales, and to estimate the influence of key physiological and environmental factors on forest ecosystem carbon balance and growth processes. Models vary in complexity and scale of application, and their applicability is related to the spatial and temporal resolution of represented processes. In general, smaller time steps and finer spatial resolution increase the number of parameters required to run models, and determine the need for a finer input data set. Therefore, it is advisable to refine simple models to allow estimates over a wide range of forest ecosystems, with a limited number of required parameters and data input.

The 3-PG forest growth model proposed by Landsberg and Waring (1997) is a widely applied, simple process-based model, which has been frequently chosen for its suitability and relative simplicity in reproducing forest vegetation processes and their dependence on environmental constraints. Based on the canopy radiation-use efficiency concept (Monteith 1977), 3-PG estimates forest growth by assuming maximum canopy assimilation capacity is a fixed value for a given vegetation type, further modulated by environmental constraints, such as temperature, air vapour pressure deficit, and soil water availability. Due to the limited number of input variables and parameters required, 3-PG has been applied to a number of forest ecosystems from widely variable climate and site conditions (e.g. Law et al. 2000; Makela et al. 2008).

In some applications, the model has been modified by exclusion or introduction of sub-models. For example, 3-PG was developed towards a remotely sensed driven version to produce forest productivity estimates at the regional scale using satellitederived data (Coops et al. 1998; Tickle et al. 2001); or modified by the introduction of a soil respiration routine to estimate ecosystem net productivity (e.g. Nolè et al. 2009); in other cases, 3-PG was combined with soil organic matter decomposition submodels to represent soil carbon dynamics (Xenakis et al. 2008).

The monthly time step basis of the 3-PG model, including a monthly average climatic input data set, can be considered a major simplification and reduces its potential to portray ecosystem carbon balance dependence on short-term weather patterns, as observed in Mediterranean ecosystems (Chiesi et al. 2012; Pereira et al. 2007). An improved 3-PG capability to describe soil water balance should also be viewed as an important model feature to interpret forest growth as a function of soil water dynamics, and possibly extend model use to catchment water balance estimates (Feikema et al. 2010).

During the last two decades, our capability to validate predictive process-based models of ecosystem carbon balance and productivity has substantially been improved by the availability of large scale data sets generated by eddy covariance flux measurements, performed over a broad range of forest types worldwide (McCarthy et al. 2012).

As a result of the above considerations and opportunities, the specific objectives of our study were to assess the capability of a modified 3-PG model to capture the temporal variation in gross primary productivity (GPP) and ecosystem net carbon uptake (NEE) in Mediterranean forest ecosystems. The effects of soil water availability on assimilation processes and productivity were better represented by upgrading the model from a monthly to daily time step, and enriching the model with an improved soil water balance routine. Following these modifications, the model was evaluated against 3-year seasonal GPP and NEE dynamics from eddy covariance flux measurements performed at two Mediterranean forest types in Italy.

\section{Materials and methods}

\subsection{Model description}

Our current 3-PG model version, $3-\mathrm{PG}_{\text {day }}$ that operates on a daily basis, retained the original 3-PG assumptions and equations (see Landsberg and Waring 1997; Coops et al. 1998) to calculate canopy gross primary production (GPP). GPP was determined as the product of radiation intercepted by the canopy, and radiation-use efficiency for carbon fixation:

$\mathrm{GPP}=\mathrm{aPAR} \cdot \varepsilon_{\max } \cdot f_{\mathrm{x}}$

where aPAR is canopy absorbed photosynthetic active radiation, $\varepsilon_{\max }$ is the biome-specific constant for radiation-use efficiency, and $f_{\mathrm{x}}$ is the summary modifier for environmental constraints, obtained as the product of single environmental modifiers; canopy aPAR was estimated as the product of daily totals incident PAR and MODIS-derived $f_{\mathrm{PAR}}$ (see below for details on MODIS data).

For our modelling exercise, environmental constraints on GPP included air temperature, available light, air vapour pressure deficit, and available soil water, with corresponding modifiers respectively denoted as $f_{\mathrm{L}}, f_{\mathrm{D}}, f_{\theta}, f_{\mathrm{T}}$. The summary modifier $f_{\mathrm{x}}$ ranges were between zero (system totally constrained) and 1 (no constraint acting on the system). All modifiers were calculated on a daily basis.

\section{פ̂sriager}


Here we report the basic modifier estimate equations; a list of equation parameters, with their descriptions and values used in the simulations, is given in Table 1.

The temperature modifier $\left(f_{\mathrm{T}}\right)$ was calculated following Sands and Landsberg (2002):

$f_{\mathrm{T}}=\left(\frac{T_{a v}-T_{\min }}{T_{o p t}-T_{\min }}\right) \times\left(\frac{T_{\max }-T_{a v}}{T_{\max }-T_{\text {opt }}}\right)^{\left(\frac{T_{\max }-T_{o p t}}{T_{\text {opt }}-T_{\min }}\right)}$

where $T_{\mathrm{av}}$ is the average daily air temperature, and $T_{\min }, T_{\max }$, and $T_{\text {opt }}$ are respectively minimum, maximum, and optimum air temperatures for photosynthesis.

The effects of gradual GPP saturation with increasing irradiance (e.g. Baldocchi and Harley 1995) were included, applying a light modifier $\left(f_{\mathrm{L}}\right)$, and integrated as a hyperbolic function of absorbed photosynthetic active radiation (aPAR), using the derivation reported by Makela et al. (2008):

$f_{\mathrm{L}}=\frac{1}{\xi \cdot a P A R+1}$

where $\xi$ is an empirical parameter.

The vapour pressure deficit modifier $\left(f_{\mathrm{D}}\right)$ was calculated following the original work of Landsberg and Waring (1997):

$f_{\mathrm{D}}=\exp (-k \cdot D)$

Table 1 Main environmental characteristics of study sites

\begin{tabular}{lll}
\hline & Castelporziano & $\begin{array}{l}\text { Arca di Noè-Le } \\
\text { Prigionette }\end{array}$ \\
\hline $\begin{array}{l}\text { Geographic location } \\
\text { Latitude, longitude }\end{array}$ & $\begin{array}{l}\text { Central Italy } \\
41^{\circ} 45^{\prime} \mathrm{N}, 12^{\circ} 22^{\prime} \mathrm{E}\end{array}$ & $\begin{array}{l}\text { Sardinia } \\
40^{\circ} 36^{\prime} \mathrm{N}, 8^{\circ} 9^{\prime} \mathrm{E}\end{array}$ \\
$\begin{array}{l}\text { Altitude (m a.s.1.) } \\
\text { Mean temperature }\end{array}$ & 7 & 74 \\
$\quad 15.5$ & 15.9 \\
$\begin{array}{l}\text { Mean-2007 }\left({ }^{\circ} \mathrm{C}\right) \\
\text { 2005-2007 (mm) }\end{array}$ & 740 & 588 \\
$\begin{array}{l}\text { Forest type } \\
\text { Canopy leaf area index } \\
\quad \text { (m }{ }^{2} \mathrm{~m}^{-2} \text { ) }\end{array}$ & 3.5 & Melm oak $(>90 \%)$ \\
$\begin{array}{l}\text { Soil depth (m) } \\
\begin{array}{l}\text { Soil texture } \\
\quad(\text { clay, sand, silt, \%) }\end{array}\end{array}$ & 0.5 & 2.8 \\
\end{tabular}

Further information on study sites can be found at the following URL: http:// www.fluxnet.ornl.gov/fluxnet/sitepage.cfm?SITEID=534 (Castelporziano); http://www.fluxnet.ornl.gov/fluxnet/sitepage.cfm?SITEID=2633 (Arca di Noè-Le Prigionette) where $D$ is the daily average of air vapour pressure deficit, and $k$ is an empirical coefficient, which accounts for the effect of $D$ on stomatal conductance.

Finally, the soil water modifier $\left(f_{\ominus}\right)$ was assessed as follows:

$$
f_{\theta}=\frac{1}{1+[(1-R E W) / c]^{n}}
$$

where $c$ and $n$ are soil type-related parameters (clay soil, $c=0.4, n=3$; clay loam soil, $c=0.5, n=5$; sandy loam soil, $c=0.6, \quad n=7$; sand soil, $c=0.7, n=9$; Landsberg and Waring 1997), and REW is the soil relative extractable water, calcu- lated on a daily basis as:

$R E W=M I N\left[\frac{S W C_{d}-S W C_{W P}}{S W C_{F C}-S W C_{W P}} ; 1\right]$

where $\mathrm{SWC}_{\mathrm{d}}$ is soil water content at day $d, \mathrm{SWC}_{\mathrm{FC}}$ and $\mathrm{SWC}_{\mathrm{WP}}$ are soil water at field capacity, and at permanent wilting point, respectively.

$\mathrm{SWC}_{\mathrm{d}}, \mathrm{SWC}_{\mathrm{FC}}$, and $\mathrm{SWC}_{\mathrm{WP}}$ estimates were derived from the newly introduced soil water balance routine. $\mathrm{SWC}_{\mathrm{FC}}$ was computed as follows:

$S W C_{F C}=1-\frac{\rho_{\mathrm{b}}}{\rho_{\mathrm{s}}}$

where $\rho_{\mathrm{b}}$ and $\rho_{\mathrm{s}}$ are soil bulk density and soil particle density, respectively.

$\mathrm{SWC}_{\mathrm{WP}}$ was determined as available soil water when soil water potential $\left(\Psi_{\mathrm{s}}\right)$ is $-1.5 \mathrm{MPa}$ (Campbell and Norman 1998); $\Psi_{\mathrm{s}}$ was calculated as proposed by Campbell (1985):

$\Psi_{s}=\Psi_{e}\left(\frac{S W C_{\mathrm{d}}}{S W C_{\mathrm{FC}}}\right)^{-b}$

where $\Psi_{\mathrm{e}}$ is the soil water potential at the point of air entry, given by:

$\Psi_{e}=\frac{-5}{\sqrt{d_{\mathrm{g}}}}\left(2 S W C_{\mathrm{FC}}\right)^{-b}$

where the texture-dependent empirical coefficient, $b$, is calculated as a function of the geometric mean particle diameter $d_{\mathrm{g}}$ and standard deviation $\sigma_{\mathrm{g}}$, based on the bimodal lognormal model proposed by Shinozawa and Campbell (1991), where $S$ and $C$ represent the fraction of silt and clay, respectively, applying the following equations: 
$b=\frac{10}{\sqrt{d_{\mathrm{g}}}}+0.2 \sigma_{g}$

$d_{\mathrm{g}}=\exp (5.756-3.454 \cdot S-7.712 \cdot C)$

$\sigma_{\mathrm{g}}=\exp \left\{\left[33.14-27.84 \cdot S-29.31 \cdot C-\left(\ln d_{\mathrm{g}}\right)^{2}\right]^{1 / 2}\right\}$

$\mathrm{SWC}_{\mathrm{d}}$ was calculated as SWC at day $d-1$, updated with daily soil water balance given by the difference between daily precipitation $\left(P_{\mathrm{d}}\right)$, and daily evapotranspiration $\left(E_{\mathrm{d}}\right)$; the excess water is assumed to run off the system if $\mathrm{SWC}_{\mathrm{d}}$ exceeds $\mathrm{SWC}_{\mathrm{FC}}$ :

$A S W_{\mathrm{d}}=\operatorname{MIN}\left\{A S W_{d-1}+P_{\mathrm{d}}-\mathrm{ET}_{d-1} ; \mathrm{ASW}_{\mathrm{FC}}\right\}$

Daily evapotranspiration was computed using the PenmanMonteith combination equation:
$E_{\mathrm{d}}=\frac{1}{\lambda} \cdot \frac{\Delta \cdot R_{\mathrm{n}}+\left(\rho_{\mathrm{a}} \cdot c_{\mathrm{p}} \cdot D\right) \cdot g_{\mathrm{bl}}}{\Delta+\gamma\left(1+g_{\mathrm{bl}} / g_{\mathrm{c}}\right)}$

where $\Delta$ is the rate of saturation specific humidity change with temperature, $R_{\mathrm{n}}$ is net radiation, $\rho_{\mathrm{a}}$ is dry air density, $c_{\mathrm{p}}$ is specific heat capacity of air, $D$ is vapour pressure deficit, $\lambda$ is the latent heat of vaporization, $\gamma$ is the psychometric constant, and $g_{\mathrm{bl}}$ and $g_{\mathrm{c}}$ are a boundary layer and the canopy conductance, respectively.

The canopy conductance $g_{\mathrm{c}}$ was calculated, according Landsberg and Waring (1997), using the following expressions:

$g_{\mathrm{c}-\mathrm{opt}}=\operatorname{MIN}\left\{\left(g_{\mathrm{s}-\mathrm{opt}} \cdot L A I\right) ; g_{\mathrm{c}-\max }\right\}$

$g_{\mathrm{c}}=g_{\mathrm{c}-\mathrm{opt}} \cdot f_{\mathrm{D}-\theta} \cdot f_{\mathrm{T}}$

where $g_{\text {s-opt }}$ is optimal stomatal conductance, $g_{\text {c-max }}$ is maximum canopy conductance, $g_{\mathrm{c}-\mathrm{opt}}$ is optimal canopy conductance, and $f_{\mathrm{D}-\Theta}$ and $f_{\mathrm{T}}$ are previously defined modifiers.
Fig. 1 Seasonal daily temperature $\left({ }^{\circ} \mathrm{C}\right)$ and precipitation (millimeters) patterns reported at study sites during 2005, 2006, and 2007; a Arca di Noè-Le Prigionette. b Castelporziano
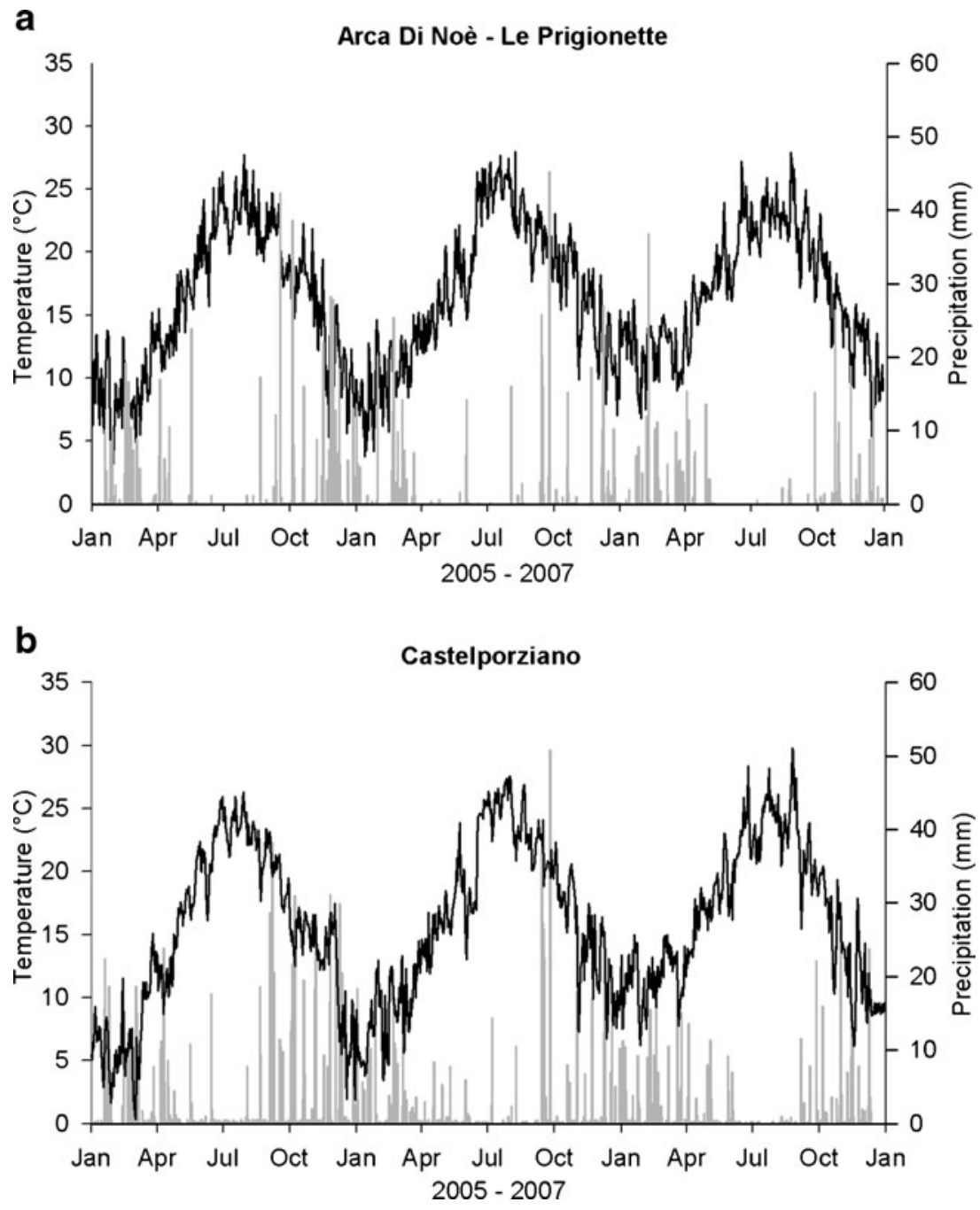
Vapour pressure deficits and available soil water independently affect carbon dioxide uptake via their effects on stomatal conductance; in $3-\mathrm{PG}_{\text {day }}$ the effects of these parameters were accounted for by a modifier $\left(f_{\mathrm{D}-\theta}\right)$, which represented, at each moment, the minimum value between $f_{\mathrm{D}}$ and $f_{\mathrm{\theta}}$ :

$f_{\mathrm{D}-\theta}=\operatorname{MIN}\left(f_{\mathrm{D}} ; f_{\theta}\right)$

Net ecosystem exchange (NEE) was estimated as the difference between GPP and ecosystem respiration $\left(R_{\text {eco }}\right)$, where $R_{\text {eco }}$ is the sum of autotrophic ( $R_{\mathrm{a}}$, including above- and belowground components), and heterotrophic $\left(R_{\mathrm{e}}\right)$ respiration, i.e.:

$$
\begin{aligned}
& \mathrm{NEE}=\mathrm{GPP}-R_{\text {eco }} \\
& R_{\text {eco }}=R_{\mathrm{a}}+R_{e}
\end{aligned}
$$

Following the original assumption (Landsberg and Waring 1997), $R_{\mathrm{a}}$ was considered a constant GPP fraction, as follows:

$R_{\mathrm{a}}=0.53 \cdot \mathrm{GPP}$

Reichstein et al. (2003) estimated soil respiration $\left(R_{\text {soil }}\right)$ as a function of soil temperature and soil water availability:

$R_{\text {soil }}=R_{\text {ref }} \cdot f\left(T_{\text {soil }} \cdot \mathrm{RWC}_{\text {soil }}\right) \cdot g\left(\mathrm{RWC}_{\text {soil }}\right)$

where $R_{\text {ref }}$ is soil respiration under standard conditions ( $T_{\text {soil }}=18^{\circ} \mathrm{C}$ and non-limiting water), $T_{\text {soil }}$ is soil temperature, $\mathrm{RWC}_{\text {soil }}$ is soil relative water content (i.e. ratio between soil water content at a given time, and soil water content at field capacity), and $f$ and $g$ are empirical parameters.

Soil respiration estimated by (Eq. 21) includes both heterotrophic and autotrophic contributions to soil respiration. This introduced the problem of double accounting the autotrophic component of soil respiration, which is already computed by the model as a constant fraction of GPP (Eq. 20). In this study, soil heterotrophic respiration was assumed to be $55 \%$ of the total soil respiration based on recent experimental evidence, including Mediterranean forest ecosystems (Tedeschi et al. 2006; Keith et al. 2009), and supported by a review (BondLamberty et al. 2004), which summarized soil respiration data from different forest types under different climatic conditions. Therefore, NEE was computed as follows:

$\mathrm{NEE}=\mathrm{GPP}-\left(R_{\mathrm{a}}+0.55 \cdot R_{\mathrm{soil}}\right)$

\subsection{Study sites}

The model was applied to simulate temporal GPP and NEE patterns at two Mediterranean sites in Italy: Castelporziano in Central Italy, and Arca di Noè-Le Prigionette in Sardinia. See Table 1 for site geographic characteristics, and Fig. 1 for weather patterns during the study period. In Castelporziano, the vegetation type is characterized as an evergreen holm oak (Quercus ilex L.) dominated forest with scattered Quercus suber L. trees; in Arca di Noè-Le Prigionette, the vegetation is Mediterranean maquis in which Juniperus phoenicea L., Pistacia lentiscus L., and Phyllirea angustifolia L. are the

\begin{tabular}{|c|c|c|c|c|}
\hline Parameter & Symbol & Unit & Value & Reference \\
\hline Radiation-use efficiency, max & $\varepsilon_{\max }$ & $\mathrm{GC} \mathrm{mol}{ }_{\mathrm{PAR}}^{-1}$ & 0.35 & Landsberg and Waring (1997) \\
\hline Stomatal conductance sensitivity to $D$ & $k$ & $\mathrm{Mbar}^{-1}$ & 0.05 & Xenakis et al. (2008) \\
\hline Minimum temperature for tree growth & $T_{\min }$ & ${ }^{\circ} \mathrm{C}$ & 0 & Hoff et al. (2002) \\
\hline Maximum temperature for tree growth & $\mathrm{T}_{\max }$ & ${ }^{\circ} \mathrm{C}$ & 40 & Hoff et al. (2002) \\
\hline Optimal temperature for tree growth & $T_{\mathrm{opt}}$ & ${ }^{\circ} \mathrm{C}$ & 20 & Hoff et al. (2002) \\
\hline Light modifier parameter & $\xi$ & Dimensionless & 0.0437 & Makela et al. (2008) \\
\hline Relative soil water modifier & $\alpha$ & Dimensionless & 1.062 & Makela et al. (2008) \\
\hline Relative soil water modifier (exponential) & $\nu$ & Dimensionless & 11 & Makela et al. (2008) \\
\hline Maximum canopy conductance & $g_{\mathrm{c}-\max }$ & $\mathrm{ms}^{-1}$ & 0.02 & Breuer et al. (2003) \\
\hline Optimal stomatal conductance & $g_{\mathrm{s}-\mathrm{opt}}$ & $\mathrm{ms}^{-1}$ & 0.004 & Breuer et al. (2003) \\
\hline Canopy boundary layer conductance & $g_{\mathrm{b} 1}$ & $\mathrm{~ms}^{-1}$ & 0.2 & Sands and Landsberg (2002) \\
\hline GPP/NPP ratio & $\gamma_{\mathrm{GPP} / \mathrm{NPP}}$ & Dimensionless & 0.47 & Landsberg and Waring (1997) \\
\hline Reference soil respiration & $R_{\text {ref }}$ & $\mu \mathrm{mol} \mathrm{m}{ }^{-2} \mathrm{~s}^{-1}$ & 5.13 & Reichstein et al. (2003) \\
\hline Lower temperature for soil respiration & $T_{0}$ & ${ }^{\circ} \mathrm{C}$ & -46 & Reichstein et al. (2003) \\
\hline RWC for half-maximum soil respiration & $\mathrm{RWC}_{1 / 2}$ & Dimensionless & 0.16 & Reichstein et al. (2003) \\
\hline Activation energy $E_{0}$ parameter & $a_{\text {rew }}$ & $\mathrm{K}^{-1}$ & 52.4 & Reichstein et al. (2003) \\
\hline Activation energy $E_{0}$ parameter & $b_{\text {rew }}$ & $\mathrm{K}^{-1}$ & 285 & Reichstein et al. (2003) \\
\hline
\end{tabular}

Table 2 List of parameters in model equations 
Fig. 2 Seasonal daily soil water content (SWC) patterns predicted by $3-\mathrm{PG}_{\text {day }}\left(\mathrm{SWC}_{3-\mathrm{PGday}}\right)$, and soil water content $\left(\mathrm{SWC}_{\mathrm{EC}}\right)$ measured at the study sites during 2005, 2006, and 2007; a Arca di Noè-Le Prigionette. b Castelporziano; SEE standard error of the estimate
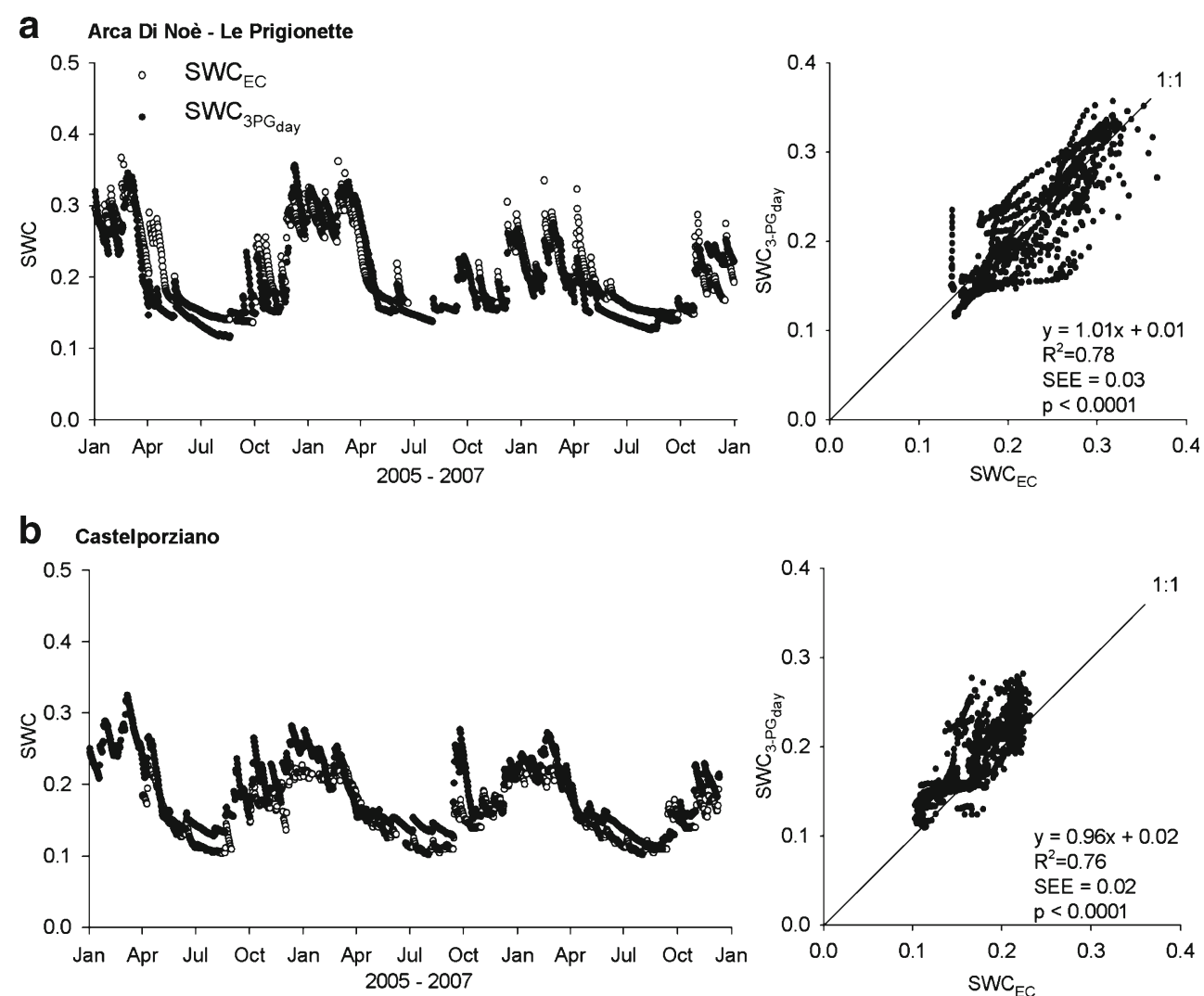

prevailing species. The two study sites were well differentiated by their soil physical characteristics, both in terms of soil depth and soil texture (sandy soil in Castelporziano and clay soil in Arca di Noè-Le Prigionette).

\subsection{Input variables and simulation procedures}

Input meteorological variables included daily averages of air $\left(T_{\text {air }}\right)$ and soil $\left(T_{\text {soil }}\right)$ temperatures, daily averages of air vapour pressure deficit $(D)$, daily precipitation $(P)$, daily totals of short-wave global radiation total $\left(R_{\mathrm{sw}}\right)$ and incident photosynthetic active radiation (PAR), and daily values of soil water content (SWC). Both study sites host eddy covariance flux towers, and all meteorological variables were obtained from High Quality Level 4 data sets in the European Fluxes Database Cluster database, available at the following URL: http://gaia.agraria.unitus.it. The same data source provided information on soil characteristics, including soil depth, texture, and water holding capacity.

Canopy leaf area index and the fraction of photosynthetically active radiation absorbed by the canopy $\left(f_{\text {PAR }}\right)$ were derived from MODIS products (MOD15A2 Leaf Area Index-FPAR), available for downloading at the following URL: https://lpdaac. usgs.gov/products/modis products table). Canopy absorbed PAR (aPAR) was estimated as the product of incident PAR and MODIS-derived $f_{\mathrm{PAR}}$.
The model was applied to estimate temporal patterns of GPP and NEE over 3 years $(2005,2006$, and 2007). At both sites, the model was initialized using field measurements of soil water content on January 1, 2005; subsequently, the model was initialized by calculating soil water balance, and converted into the soil water modifier (Eq. 5). The model successively calculated the other environmental modifiers required to estimate GPP and NEE as previously described. The model was parameterized using values derived from the literature. No calibration or tuning of model parameters using site measurements was done. The only site-specific parameters, measured at the study sites, were related to soil characteristics (soil texture and soil depth). Model parameters are listed in Table 2).

\subsection{Validation data and model performance}

Model results were compared to daily soil water content and eddy covariance (EC) flux measurements performed at the two study sites over 3 years (2005-2007); daily net ecosystem exchange $\left(\mathrm{NEE}_{\mathrm{EC}}\right)$ and ecosystem respiration $\left(R_{\mathrm{eco}-\mathrm{EC}}\right)$ data were retrieved from the High Quality Level 4 data sets in the CarboEuropeIP database, and GPP $\mathrm{EC}_{\mathrm{E}}$ was calculated according to the following algebraic sum:

$\mathrm{GPP}_{\mathrm{EC}}=\mathrm{NEE}_{\mathrm{EC}}+R_{\text {eco }}$ 
Fig. 3 Left panels: seasonal patterns of daily gross primary production (GPP) predicted by 3-PG $\mathrm{PGy}_{\text {day }}\left(\mathrm{GPP}_{3-\mathrm{PGday}}\right)$, and gross primary production $\left(\mathrm{GPP}_{\mathrm{EC}}\right)$ measured at the study sites during 2005, 2006, 2007. Right panels: linear regression between $\mathrm{GPP}_{3-}$ PGday and $\mathrm{GPP}_{\mathrm{EC}}$. a Arca di NoèLe Prigionette. b Castelporziano; SEE standard error of the estimate
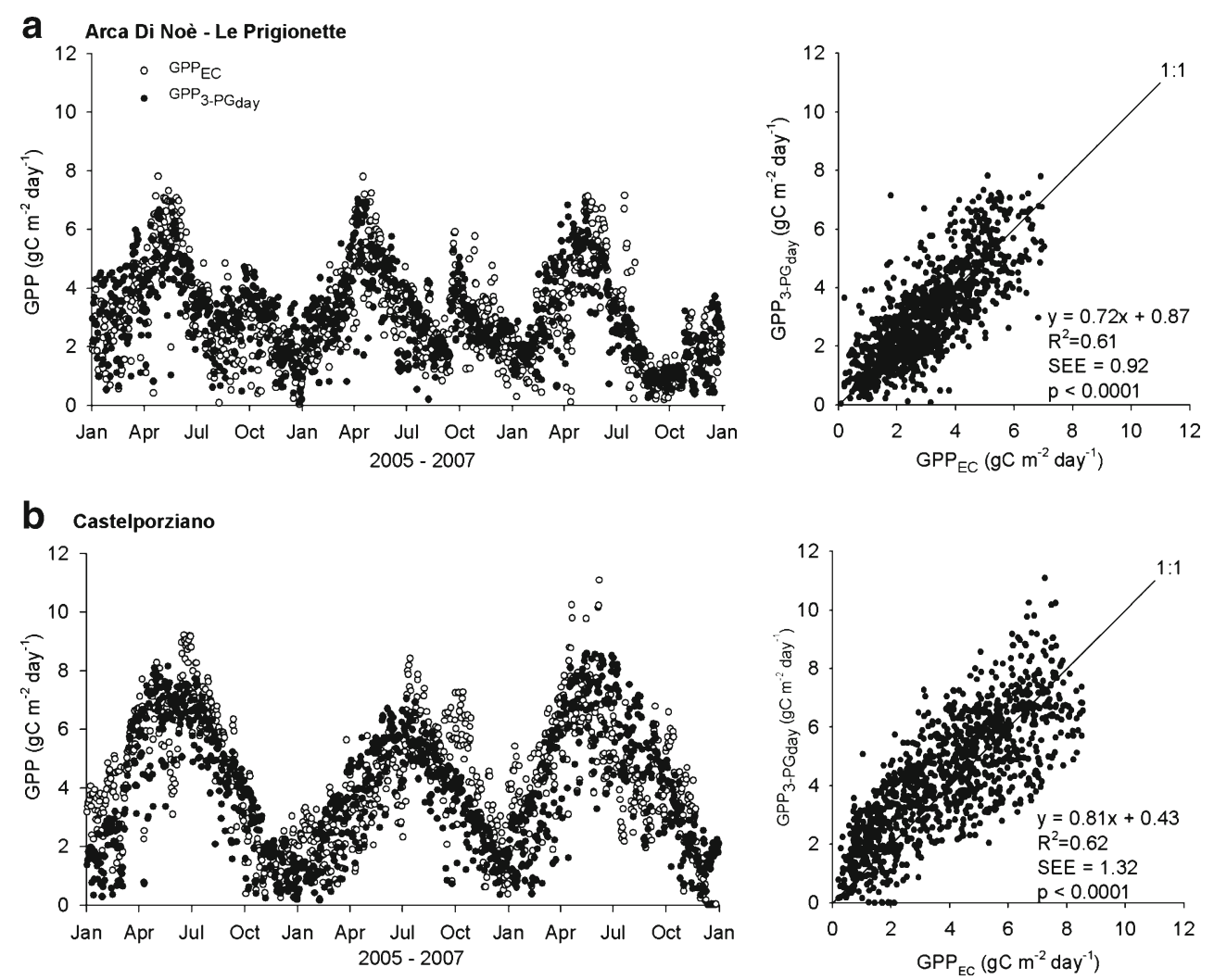

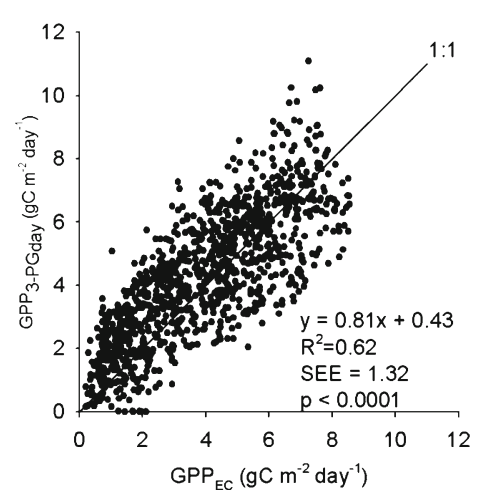

Model performance was assessed by considering the absolute model bias (Bias), and the coefficient of determination $\left(R^{2}\right)$, calculated as follows:

$$
\begin{gathered}
\text { Bias }=\sum_{i=n}^{n}\left(y_{i}-\hat{y}\right) / n \\
R^{2}=\frac{\sum_{i=n}^{n}\left(y_{i}-\hat{y}\right)^{2}}{\sum_{i=n}^{n}\left(y_{i}-\bar{y}\right)^{2}}
\end{gathered}
$$

where $y_{i}$ is the measured value, $\hat{y}$ is the estimated (modelled) value, and $\bar{y}$ is the average of the measured $y$ values.

\section{Results}

Our 3-PG model, including the soil water balance routine, realistically simulated temporal variation in soil water content (SWC). At both study sites, simulated and measured SWC values agreed well throughout the entire study period, with significant linear relationships, and rather coincident peaks and troughs (Fig. 2).

The model effectively described GPP (Fig. 3) and NEE (Fig. 4) seasonal patterns at both study sites throughout 2005,
2006, and 2007. It is noteworthy that the model accurately represented long-term seasonal patterns. As for short-term (over a few days) temporal variation, the model captured minor GPP peaks that occurred following rainfall during autumn 2005 and 2006 in Arca di Noè-Le Prigionette; however, it missed the peaks in July 2005 and November 2006 at Castelporziano. The transition of both forest communities from a carbon sink to a carbon source, under summer heat and rainfall deficits, was effectively represented (Fig. 4); NEE ranged between -4 and 2 , and -8 and $2 \mathrm{~g} \mathrm{C} \mathrm{m}^{-2}$ day $^{-1}$ in Arca di Noè-Le Prigionette and Castelporziano.

The model captured seasonal ecosystem respiration $\left(R_{\mathrm{eco}}\right)$ patterns satisfactorily; however, it failed to predict short-term anomalies (Fig. 5).

Annual totals of GPP, NEE, and $R_{\text {eco }}$ are reported in Table 3. Results were congruent with measured and modelled values at both sites for the entire study period.

Model performance was further assessed by plotting 8day aggregated Bias (Eq. 24) values against main environmental variables (air temperature, $T_{\text {air }}$; relative soil water content, $\mathrm{RSW}_{\text {soil }}$; fraction of absorbed photosynthetic active radiation, $f_{\mathrm{PAR}}$; soil temperature, $\left.T_{\text {soil }}\right)$. Despite the rather large environmental range explored, no significant relationship was detected between simulated variables (GPP, NEE, $R_{\text {eco }}$ ) Bias and environmental variables (Figs. 6, 7, and 8). Variation in $R^{2}$ estimator (Eq. 25) was successively used to describe the correlation strength between modelled and 
Fig. 4 Left panels: seasonal patterns of daily net ecosystem exchange (NEE) predicted by 3 $\mathrm{PG}_{\text {day }}\left(\mathrm{NEE}_{3 \text {-PGday }}\right)$, and net ecosystem exchange $\left(\mathrm{NEE}_{\mathrm{EC}}\right)$ measured at the study sites during 2005, 2006, and 2007; right panels: linear regression between $\mathrm{NEE}_{3 \text {-PGday }}$ and $\mathrm{NEE}_{\mathrm{EC}}$. a Arca di Noè-Le Prigionette. b Castelporziano; SEE standard error of the estimate
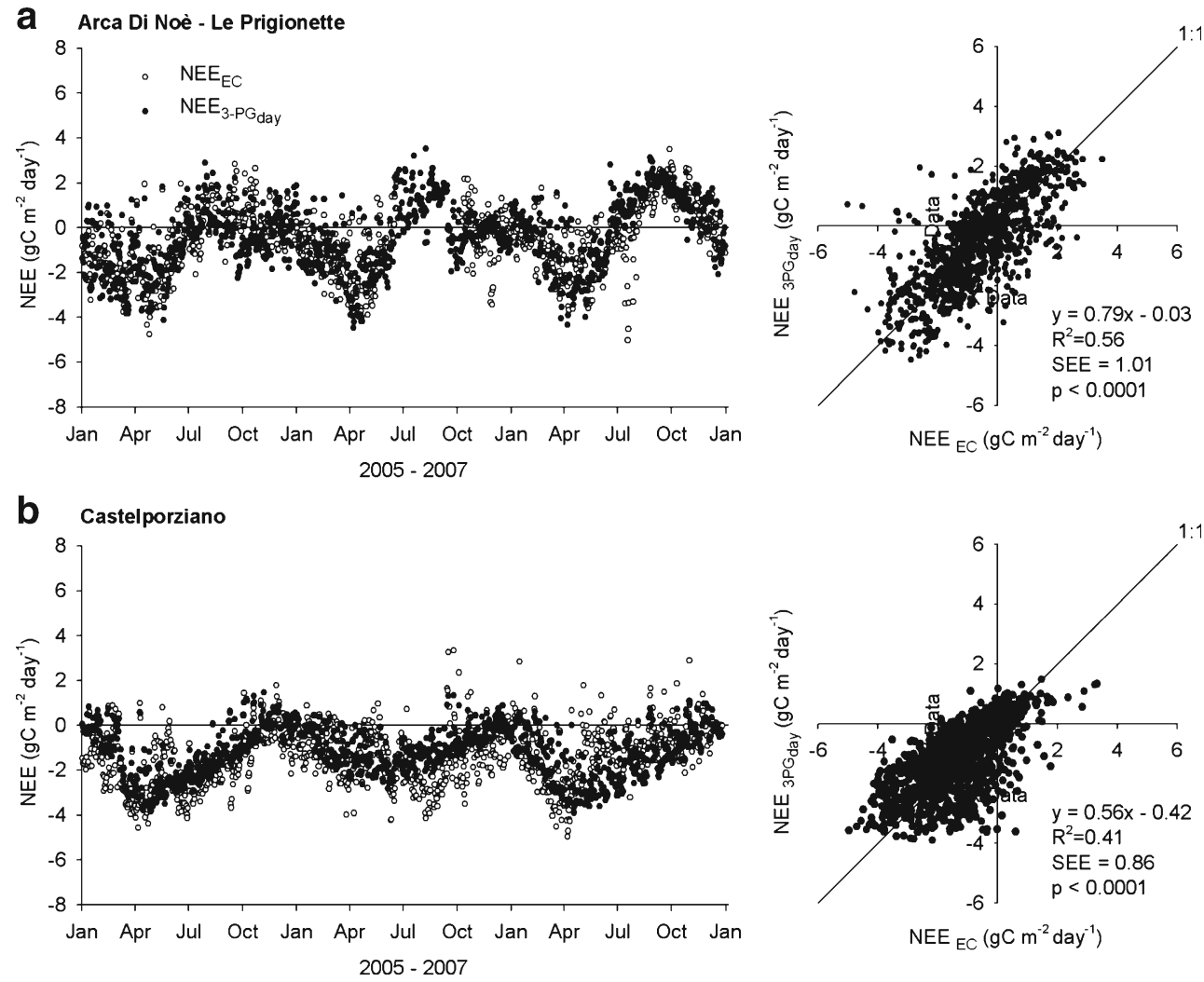

measured values. $R^{2}$ variation as a $T_{\text {air }}, \mathrm{RWC}_{\text {soil }}$, and $f_{\mathrm{PAR}}$ function suggests the GPP and NEE model predictions were weaker with increasing temperature and decreasing relative soil water content (Fig. 9).
Fig. 5 Left panels: seasonal daily ecosystem respiration patterns $\left(R_{\text {eco }}\right)$ predicted by $3-\mathrm{PG}_{\text {day }}\left(R_{\text {eco3-PGday }}\right)$, and ecosystem respiration $\left(R_{\text {ecoEC }}\right)$ measured at the study sites during 2005, 2006, and 2007; right panels: linear regression between $R_{\text {eco3-PGday }}$ and $R_{\text {ecoEC }}$. a Arca di Noè-Le Prigionette. b Castelporziano; SEE standard error of the estimate
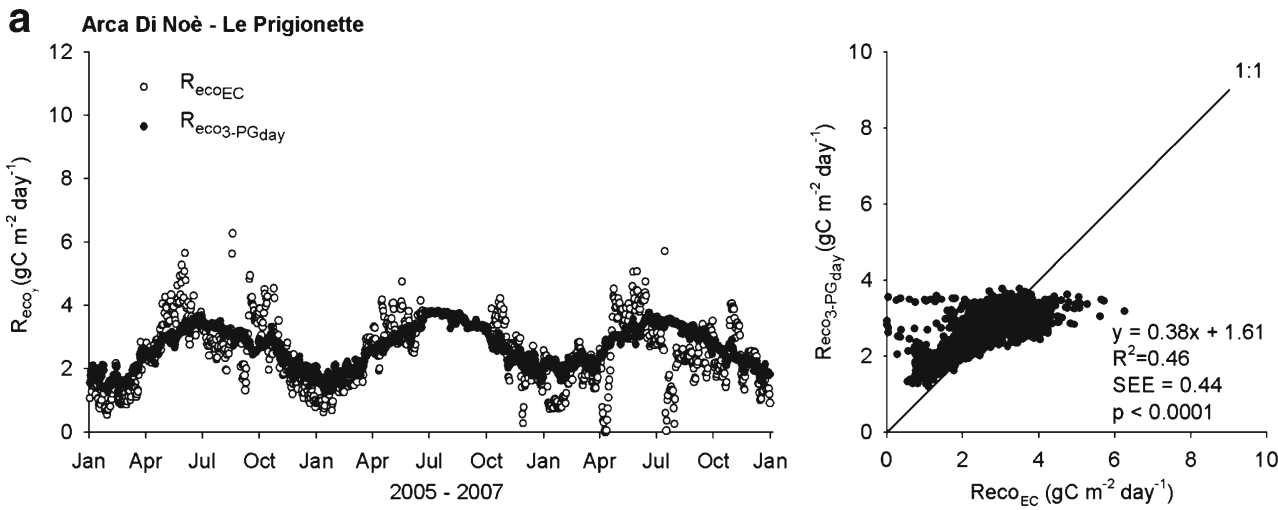

b

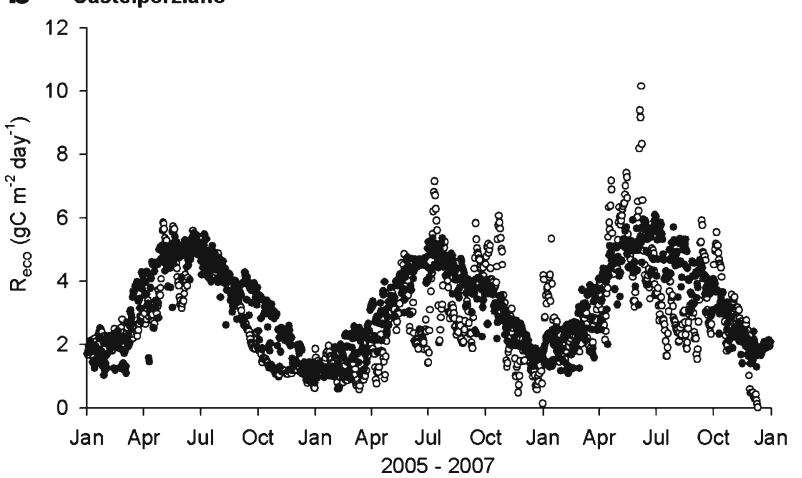


Table 3 Annual values (grams of C per square meter per year) of measured (EC subscript) and modeled (3-PGday subscript) GPP (gross primary production), NEE (net ecosystem exchange), and $R_{\text {eco }}$ (ecosystem respiration) at Arca di Noè-Le Prigionette and Castelporziano study sites during 2005, 2006, and 2007

\begin{tabular}{lllllllll}
\hline & \multicolumn{3}{c}{ Arca di Noè-Le Prigionette } & & \multicolumn{3}{c}{ Castelporziano } \\
\cline { 2 - 3 } \cline { 8 - 9 } & 2005 & 2006 & 2007 & & 2005 & 2006 & 2007 \\
\hline GPP $_{\text {3-PGday }}$ & 1,201 & 1,158 & 953 & & 1,660 & 1,399 & 1,634 \\
$\mathrm{GPP}_{\text {EC }}$ & 1,155 & 1,178 & 942 & & 1,635 & 1,409 & 1,574 \\
$\mathrm{NEE}_{3-P G d a y}$ & -271 & -256 & -30 & & -589 & -293 & -486 \\
$\mathrm{NEE}_{\mathrm{EC}}$ & -237 & -249 & -90 & & -603 & -496 & -417 \\
$R_{\text {eco3-PGday }}$ & 894 & 613 & 984 & & 1,074 & 1,137 & 1,154 \\
$R_{\text {ecoEC }}$ & 888 & 621 & 854 & & 1,033 & 914 & 1,157 \\
\hline
\end{tabular}

Negative NEE values indicate carbon uptake from the atmosphere (i.e. the system acts as a $\mathrm{CO}_{2}$ sink)

\section{Discussion}

Trends toward higher temperatures and reduced precipitation are predicted to produce unfavourable soil water balance conditions in Mediterranean region causing intense drought stress (Williams et al. 2013), the decline of forest trees, and possible transition of forest ecosystems to shrubland-type or steppic vegetation.

This might come as the result of the crucial role of soil water availability in constraining plant gas exchange and carbon uptake. For this reason, a viable representation of soil water content variability over drought onset and progression is considered an important prerequisite for modelling forest primary productivity and carbon balance under Mediterranean conditions.

The previous 3-PG model version, similar to the 3-PGS version presented by Nolè et al. (2009), showed an overestimate of gross primary productivity (GPP) during summer months in Mediterranean sites with low precipitation, consistent with results reported by Law et al. (2000). The discrepancies were likely associated with an overly simplified representation of soil water availability, and consequent inaccurate effects on physiological processes.

In our attempts to upgrade the original 3-PG model structure from a monthly to daily time step, we implemented a routine to better represent soil water availability. Feikema et al. (2010) successfully introduced a rather complex multilayer soil water balance into 3-PG to simulate forest plantation transpiration in southeastern Australia. We similarly assumed the effect of progressive drought on plant physiology could be conveniently obtained by water balancedriven temporal development of soil water availability; however, our application was simpler and less demanding, and was parameterized as a single-layer bucket representation of soil water availability.

We followed the direction of Duursma et al. (2008), which showed daily plant gas exchange during drought could be reasonably predicted by a simple model restricted to the soil compartment. This is in agreement with the indication by Piedallu et al. (2013) that showed soil water balance performed better than climatic variables for modelling plant ecological parameters under Mediterranean conditions. Feikema et al. (2010) showed that the improved 3PG+model simulated daily
Fig. 6 Eight-day aggregated Bias (see Eq. 24) for GPP as a function of air temperature $\left(T_{\text {air }}\right)$, relative soil water content $\left(\mathrm{RWC}_{\text {soil }}\right)$, and fraction of absorbed photosynthetic active radiation $\left(f_{\mathrm{PAR}}\right)$ for the two study sites
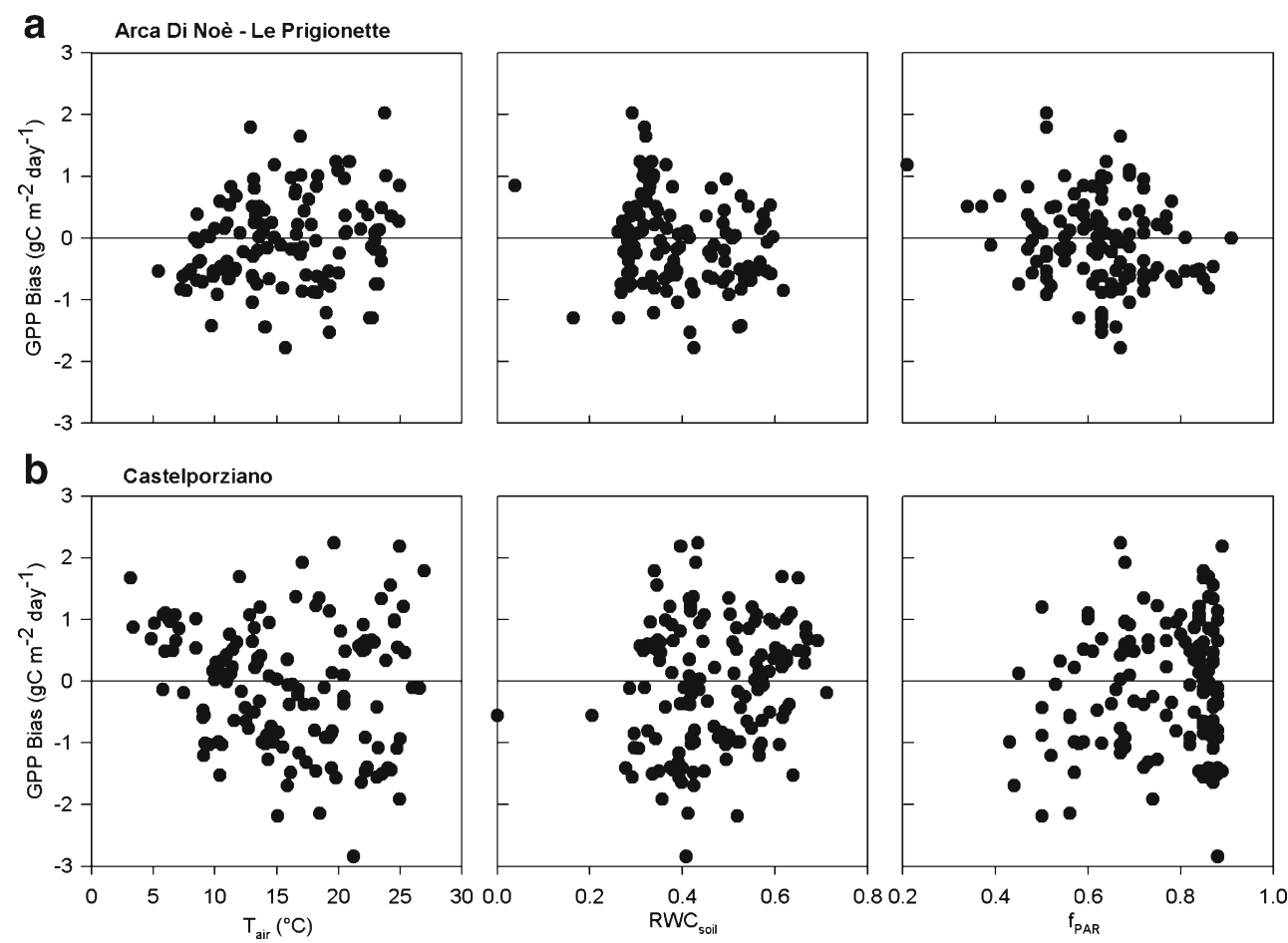
Fig. 7 Eight-day aggregated Bias (see Eq. 24) for NEE as a function of air temperature $\left(T_{\text {air }}\right)$, relative soil water content $\left(\mathrm{RWC}_{\text {soil }}\right)$, and fraction of absorbed photosynthetic active radiation $\left(f_{\mathrm{PAR}}\right)$ for the two study sites
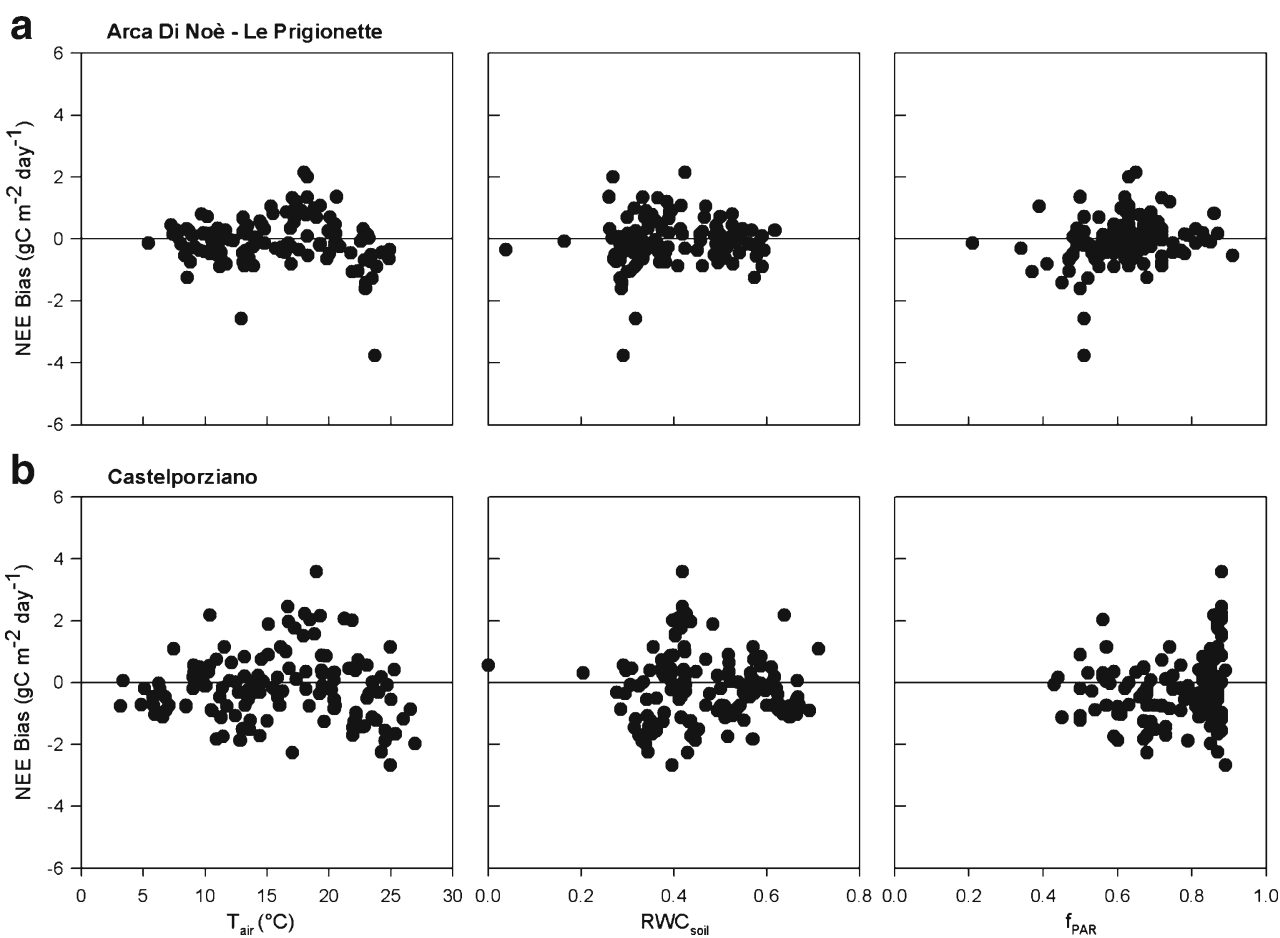

stand transpiration in reasonable agreement with observed values; however, they did not extend their analysis to standlevel carbon flux comparisons.

Our new model version satisfactorily captured seasonal patterns of both gross primary production (GPP) and net ecosystem exchange (NEE), with better prediction of GPP than NEE. The model explained daily GPP and NEE variability at both study sites, and this resulted in reliable GPP and NEE predictions on an annual basis (Table 3). During drought, the model's capacity to identify environmental conditions that change the forest from a carbon sink to a carbon source was of particular importance to ecosystem carbon balance estimates. Forest carbon uptake can be heavily affected by heat waves and rainfall deficits (e.g. Ciais et al. 2005), and even
Fig. 8 Eight-day aggregated Bias (see Eq. 24) for $R_{\text {eco }}$ as a function of soil temperature $\left(T_{\text {soil }}\right)$, relative soil water content $\left(\mathrm{RWC}_{\text {soil }}\right)$, and fraction of absorbed photosynthetic active radiation $\left(f_{\mathrm{PAR}}\right)$ for the two study sites
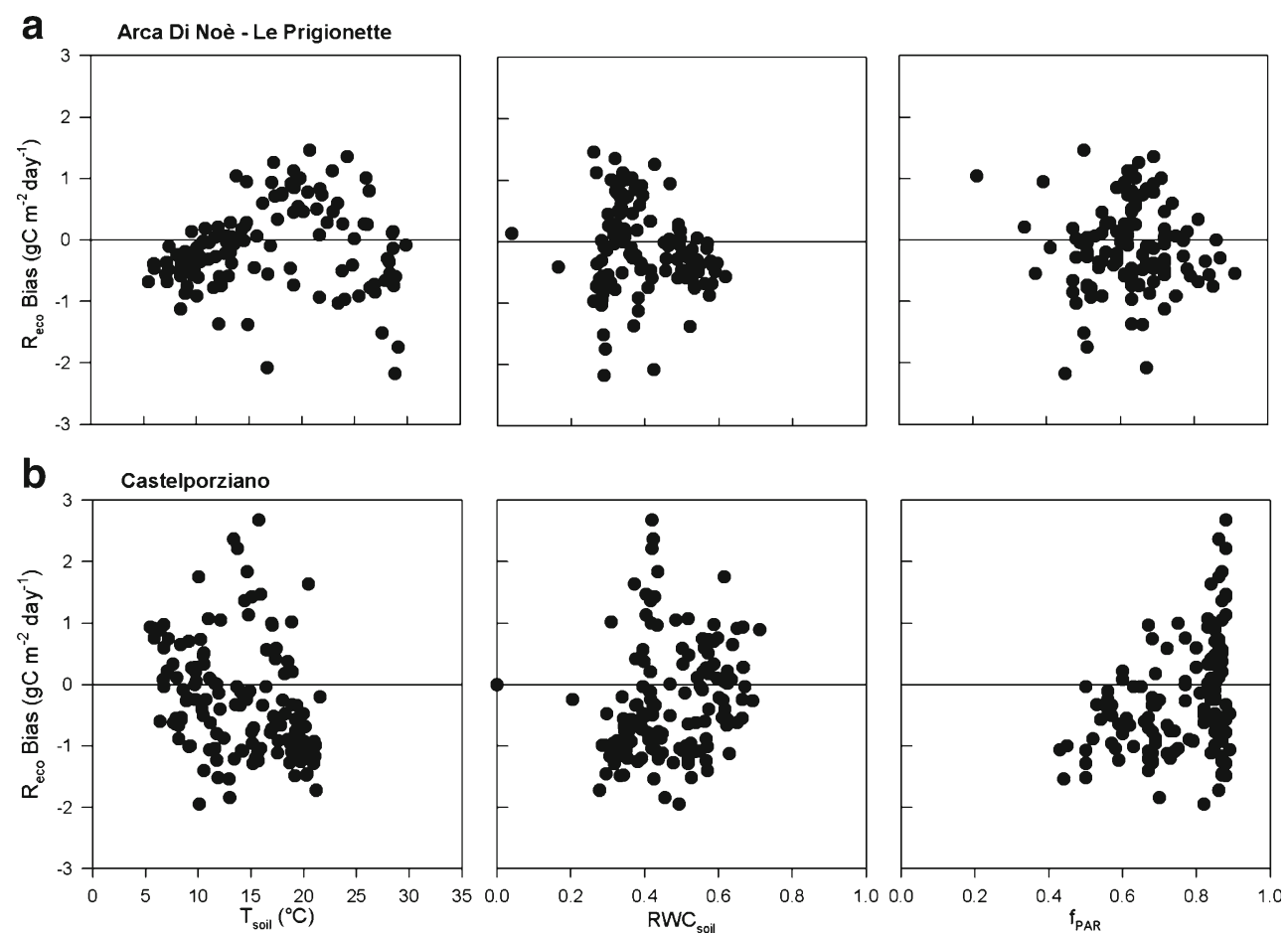
Fig. $9 R^{2}$ estimator variation (see Eq. 25) as a function of air temperature $\left(T_{\text {air }}\right)$, relative soil water content $\left(\mathrm{RWC}_{\text {soil }}\right)$, and fraction of absorbed photosynthetic active radiation $\left(f_{\mathrm{PAR}}\right)$ for GPP and NEE at the two study sites
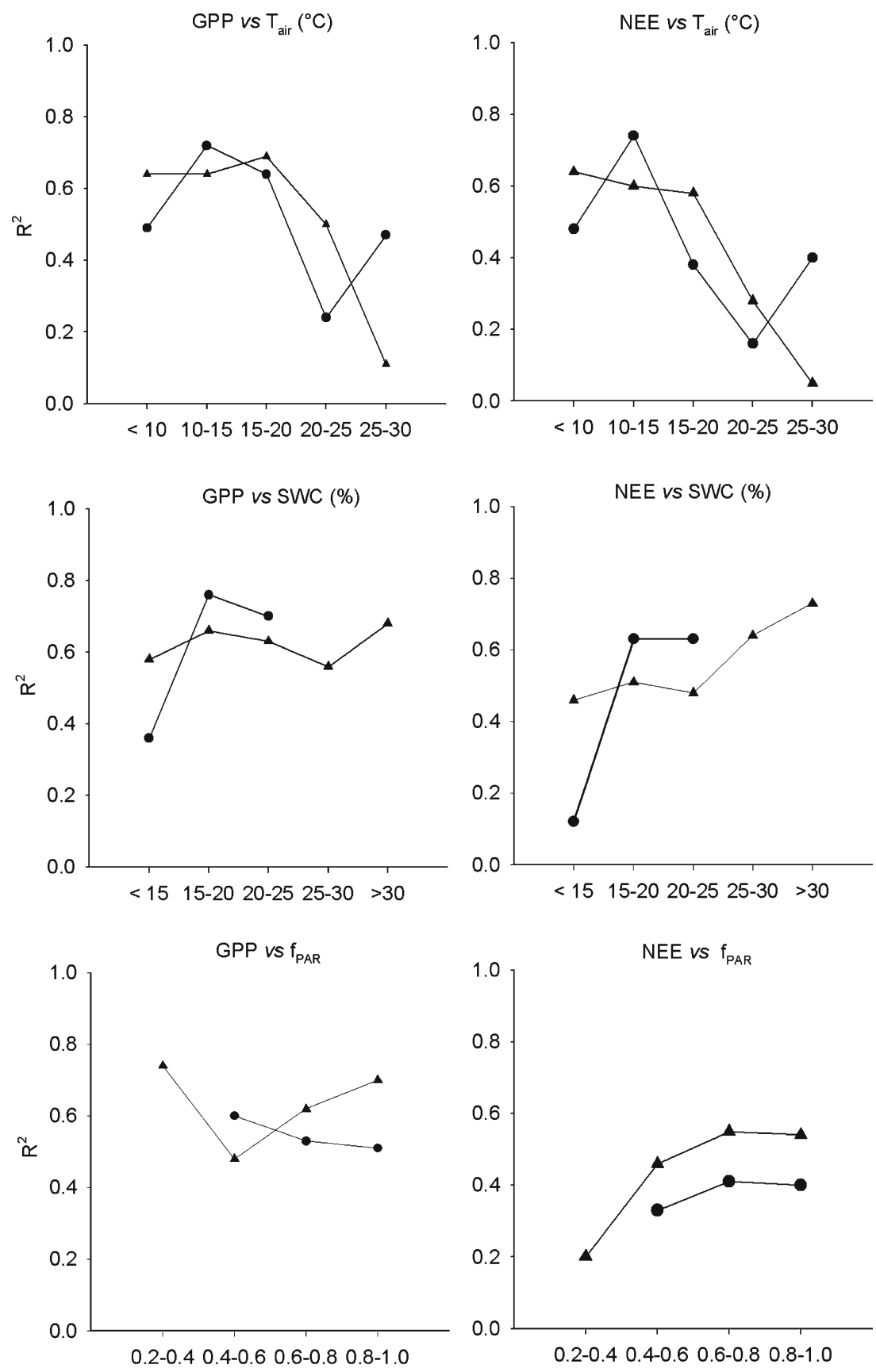

- Casteporziano

— Arca di Noè - Le Prigionette

short-term fluctuations in soil humidity, following dry soil rewetting by occasional precipitation might significantly affect forest ecosystem net carbon gain (Jarvis et al. 2007). Such conditions are predicted to become more frequent under future climatic conditions in the Mediterranean region (IPCC 2007), with accumulated effects potentially leading to droughtinduced forest decline (Anderegg et al. 2012).

Net ecosystem carbon exchange (NEE) was predicted by introducing an empirical soil respiration model in $3-\mathrm{PG}_{\text {day }}$ in which the relative soil water content, expressed as a fraction of water content at field capacity, was the crucial soil respiration $\left(R_{\text {soil }}\right)$ predictor on a daily basis (Reichstein et al. 2003; Tedeschi et al. 2006). However, to calculate ecosystem respiration $\left(R_{\text {eco }}\right) \quad 3-\mathrm{PG}_{\text {day }}$ retained the original assumption that autotrophic respiration $\left(R_{\mathrm{a}}\right)$ was a constant fraction of soil heterotrophic respiration and GPP. This may explain why the model did not generate a faithful representation of short-term fluctuations in ecosystem respiration (Fig. 5). 
Nonetheless, 3-PG $\mathrm{Pay}_{\mathrm{day}}$ successfully captured environmental conditions at Arca di Noè-Le Prigionette, when results showed that changed into a carbon source (Fig. 4). In addition, on a seasonal scale NEE model estimates were satisfactory (Table 3), which confirms the assumption that separating soil autotrophic and heterotrophic respiration does not impair the model's predictive power to long-term projections (Nolè et al. 2009).

The analysis of model Bias (Figs. 6, 7, and 8) showed that divergence between modelled and measured values was not influenced by the effects of any single environmental variable; however, correlation strength between modelled and measured values as a function of environmental variables did indicate model predictions were weaker with increasing air temperature and decreasing relative soil water content (Fig. 9). This requires careful model applications under the extreme conditions forecasted by climate projections. In particular, model sensitivity to soil humidity was interpreted as an expected consequence of the new model structure, and marked a difference with the previous model version, which was more sensitive to lower rates of atmospheric humidity rather than precipitation and soil humidity (Nolè et al. 2009). It is noteworthy that a better model performance in the simulation of soil humidity was observed for the clay-soil Arca di Noè Le Prigionette site (Fig. 2), and this could explain differences in model performance for low soil water conditions at the two sites (Fig. 9). Therefore, further improvements might be obtained with enhanced model parameterization, particularly for air temperature and soil humidity responses and especially for sandy soils. However, the semi-empirical nature and simplicity inherent in the original model formulation (Landsberg and Waring 1997) appears itself as an obstacle allowing the model to effectively predict short-term daily variations.

Overall, the modified 3-PG model, that retains sufficient simplicity in comparison with more demanding models (e.g. Chiesi et al. 2012), can be considered as a reliable tool to provide quantitative information on the potential for carbon uptake and carbon accumulation in Mediterranean droughtprone forest ecosystems and as an aid to design conservation and management strategies in order to mitigate the likely impacts of climate change on forest ecosystems dynamics.

Acknowledgments The research was supported by a grant from the MIUR-FISR CarboItaly Project and, in part, by the MIUR-PRIN project-N. 20085FL4E4_002. Angelo Nolè acknowledges a STMS COST-fellowship (FP0603) and thanks Anniki Makela (University of Helsinki) for useful discussion and advices. We thank two anonymous referees and the associate editor, Barry Gardiner, for their constructive comments on the manuscript.

\section{References}

Anderegg WRL, Berry JA, Field CB (2012) Linking definitions, mechanisms, and modeling of drought-induced tree death. Trends Plant Sci 17:693-700. doi:10.1016/j.tplants.2012.09.006
Baldocchi DD, Harley PC (1995) Scaling carbon dioxide and water vapour exchange form leaf to canopy in a deciduous forest. II. Model testing and application. Plant Cell Envir 18:1157-1173. doi:10.1111/j.1365-3040.1995.tb00625.x

Bond-Lamberty B, Wang CK, Gower ST (2004) A global relationship between the heterotrophic and autotrophic components of soil respiration? Glob Change Biol 10:1756-1766. doi:10.1111/j.13652486.2004.00816.x

Breuer L, Eckhardt K, Frede H (2003) Plant parameter values for models in temperate climates. Ecol Model 169:237-293. doi:10.1016/ S0304-3800(03)00274-6

Campbell GS (1985) Soil physics with BASIC - transport models for soilplant systems. Developments in Soil Science 14. Elsevier, New York

Campbell GS, Norman JM (1998) An introduction to environmental biophysics. Wiley, New York, p 286

Chiesi M et al (2012) Use of BIOME-BGC to simulate water and carbon fluxes within Mediterranean macchia. Forest 5:38-43. doi:10.3832/ ifor0605-009

Ciais P, Reichstein M, Viovy N et al (2005) Europe-wide reduction in primary productivity caused by the heat and drought in 2003 . Nature 437:529-533. doi:10.1038/nature03972

Coops NC, Waring RH, Landsberg JJ (1998) Assessing forest productivity in Australia and New Zealand using a physiologically-based model driven with averaged monthly weather data and satellitederived estimates of canopy photosynthetic capacity. Forest Ecol Manag 104:113-127. doi:10.1016/S0378-1127(97)00248-X

Duursma RA, Kolari P, Perämäki M, Nikinmaa E, Hari P, Delzon S, Loustau D, Ilvesniemi H, Pumpanen J, Mäkelä A (2008) Predicting the decline in daily maximum transpiration rate of two pine stands during drought based on constant minimum leaf water potential and plant hydraulic conductance. Tree Physiol 28:265-276. doi:10. 1093/treephys/28.2.265

Feikema PM, Morris JD, Beverly CR, Collopy JJ, Baker TG, Lane PNJ (2010) Validation of plantation transpiration in south-eastern Australia estimated using the $3 \mathrm{PG}+$ forest growth model. Forest Ecol Manag 260:663-678. doi:10.1016/j.foreco.2010.05.022

Giorgi F (2006) Climate change hot-spots. Geophys Res Lett 33, L08707. doi:10.1029/2006GL025734

Hoff C, Rambal S, Joffre R (2002) Simulating carbon and water flows and growth in a Mediterranean evergreen Quercus ilex coppice using the FOREST-BGC model. Forest Ecol Manag 164:121-136. doi:10.1016/S0378-1127(01)00605-3

IPCC (2007) Summary for policymakers. In: Parry ML, Canziani OF, Palutikof JP, van der Linden PJ, Hanson CE (eds) Climate Change 2007: impacts, adaptation and vulnerability. Contribution of Working Group II to the Fourth Assessment Report of the Intergovernmental Panel on Climate Change. Cambridge University Press, Cambridge, pp 7-22

Jarvis P, Rey A, Petsikos C, Wingate L, Rayment M, Pereira J, Banza J, David J, Miglietta F, Borghetti M, Manca G, Valentini R (2007) Drying and wetting of soils stimulates decomposition and carbon dioxide emission: the "Birch effect". Tree Physiol 27:929-940. doi:10.1093/treephys/27.7.929

Keith H, Leuning R, Jacobsen KL, Cleugh HA, van Gorsel E, Raison RJ, Medlyn BE, Winters A, Keitel C (2009) Multiple measurements constrain estimates of net carbon exchange by a Eucalyptus forest. Agr Forest Meteorol 149:535-558. doi:10.1016/j.agrformet.2008.10.002

Landsberg JJ, Waring RH (1997) A generalized model of forest productivity using simplified concepts of radiation-use efficiency, carbon balance and partitioning. Forest Ecol Manag 95:209-228. doi:10. 1016/S0378-1127(97)00026-1

Law BE, Waring RH, Anthoni PM, Aber JD (2000) Measurements of gross and net ecosystem productivity and water vapour exchange of a Pinus ponderosa ecosystem, and an evaluation of two generalized models. Glob Change Biol 6:155-168. doi:10.1046/j.1365-2486. 2000.00291.x 
Lindner M, Maroschek M, Netherer S, Kremer A, Barbati A, GarciaGonzalo J, Seidl R, Delzon S, Corona P, Kolström M, Lexer MJ, Marchetti M (2010) Climate change impacts, adaptive capacity, and vulnerability of European forest ecosystems. Forest Ecol Manag 259:698-709

Makela A, Pulkkinen M, Kolari P, Lagergren F, Berbigier P, Lindroth A, Loustau D, Nikinmaa E, Vesala T, Hari P (2008) An empirical model of stand GPP with the LUE approach: analysis of eddy covariance data at five contrasting conifer sites in Europe. Glob Change Biol 14:92-108. doi:10.1111/j.1365-2486.2007.01463.x

McCarthy HR, Luo YQ, Wullschleger SD (2012) Integrating empiricalmodeling approaches to improve understanding of terrestrial ecology processes. New Phytol 195:523-525. doi:10.1111/j.1469-8137. 2012.04222.x

Monteith JL (1977) Climate and the efficiency of crop production in Britain. Phil Trans R Soc B 281:277-294

Nardini A, Battistuzzo M, Savi T (2013) Shoot desiccation and hydraulic failure in temperate woody angiosperms during an extreme summer drought. New Phytol. doi:10.1111/nph.12288

Nolè A, Law BE, Magnani F, Matteucci G, Ferrara A, Ripullone F, Borghetti M (2009) Application of the 3-PGS model to assess carbon accumulation in forest ecosystems at a regional level. Can J Forest Res 39:1647-1661. doi:10.1139/X09-077

Pereira JS, Mateus JA, Aires LM, Pita G, Pio C, David JS, Andrade V, Banza J, David TS, Paço TA, Rodrigues A (2007) Net ecosystem carbon exchange in three contrasting Mediterranean ecosystems? The effect of drought. Biogeosciences 4:791-802

Piedallu C, Gégout J-C, Perez V, Lebourgeois F, Field R (2013) Soil water balance performs better than climatic water variables in tree species distribution modelling. Global Ecol Biogeogr 22:470-482. doi:10.1111/geb.12012

Reichstein M, Rey A, Freibauer A, Tenhunen J, Valentini R, Banza J, Casals P, Cheng YF, Grunzweig JM, Irvine J, Joffre R, Law BE,
Loustau D, Miglietta F, Oechel W, Ourcival JM, Pereira JS, Peressotti A, Ponti F, Qi Y, Rambal S, Rayment M, Romanya J, Rossi F, Tedeschi V, Tirone G, Xu M, Yakir D (2003) Modeling temporal and large-scale spatial variability of soil respiration from soil water availability, temperature and vegetation productivity indices. Global Biogeochem Cy 17:1104-1116. doi:10.1029/2003GB002035

Sands PJ, Landsberg JJ (2002) Parameterisation of 3-PG for plantation grown Eucalyptus globulus. Forest Ecol Manag 163:273-292. doi:10.1016/S0378-1127(01)00586-2

Shinozawa S, Campbell GS (1991) On the calculation of mean particle diameter and standard deviation from sand, silt, and clay fractions. Soil Sci 152:427-431

Tedeschi V, Rey A, Manca G, Jarvis PG, Valentini R, Borghetti M (2006) Soil respiration in a Mediterranean oak forest at different developmental stages after coppicing. Glob Change Biol 12:110-121. doi:10.1111/j.1365-2486.2005.01081.x

Tickle PK, Coops NC, Hafner SD, The Bago Science Team (2001) Assessing forest productivity at local scales across a native eucalypt forest using a process model, 3PG-SPATIAL. Forest Ecol Manag 152:275-291. doi:10.1016/S0378-1127(00)00609-5

Vitale M, Mancini M, Matteucci G, Francesconi F, Valenti R, Attorre F (2012) Model-based assessment of ecological adaptations of three forest tree species growing in Italy and impact on carbon and water balance at national scale under current and future climate scenarios. Forest 5:235-246. doi:10.3832/ifor0634-005

Williams AP, Allen CD, Macalady AK, Griffin D, Woodhouse CA, Meko DM, Swetnam TW, Rauscher SA, Seager R, Grissino-Mayer HD et al (2013) Temperature as a potent driver of regional forest drought stress and tree mortality. Nat Clim Change 3:292-297

Xenakis G, Ray D, Mencuccini M (2008) Sensitivity and uncertainty analysis from a coupled 3-PG and soil organic matter decomposition model. Ecol Model 219:1-16. doi:10.1016/j. ecolmodel.2008.07.020 